\title{
Beyond Balancing the Interests of Creditors and Developing
} States

Anna Gelpern

Georgetown University Law Center, ag1348@law.georgetown.edu

This paper can be downloaded free of charge from:

https://scholarship.law.georgetown.edu/facpub/1873

https://ssrn.com/abstract=885982

ASIL Proc. 221 (2003)

This open-access article is brought to you by the Georgetown Law Library. Posted with permission of the author. Follow this and additional works at: https://scholarship.law.georgetown.edu/facpub

Part of the Finance Commons, and the International Economics Commons 


\title{
SOVEREIGN DEBT CRISIS: CREDITOR'S RIGHTS VS. DEVELOPMENT
}

BEYOND BALANCING THE INTERESTS OF CREDITORS AND DEVELOPING STATES

\author{
by Anna Gelpern*
}

The title of our panel suggests a rather bipolar view of the sovereign debt predicament: On one side, there are foreign private creditors-a Citibank that made a loan to a developing country or a Belgian dentist that bought its bond-and their goal is to squeeze as much money as possible out of the developing country's government. On the other side, there is the government, which wants to keep as much money as possible for the people of the country.

This framing is increasingly out of date because of two trends: the increasing sophistication of domestic financial systems and the liberalization of capital flows. Developing country residents buy more and more of their governments' debt. In a restructuring, they appear on both sides of the negotiating table, as borrowers and as creditors. For example, the stock of Brazil's domestic debt securities is nearly five times the size of its external debt. ${ }^{1}$ Should Brazil's debt ever need to be restructured, it would be hard to ignore domestic holdings. As the structure and patterns of holding sovereign debt instruments become progressively more complex, the tasks of debt restructuring and economic recovery are further complicated.

Until recently there was a relatively clean division between domestic and external debt. Foreign investors lent money to governments in the investors' own currency, on terms governed by the investors' own laws, to be interpreted by the investors' home courts. When governments borrowed from their own citizens, they generally did so in the local currency, under local law, subject to the jurisdiction of the local courts. It was assumed, with some justification, that when things went bad, restructuring private external debt would be the hard part because the government had little control over the currency, the law, or the creditors. This assumption in part explains why recent policy proposals-both statutory and contractual-focus on private external bonds. It was thought that the government would take care of domestic debt by printing more currency, restructuring by decree, or arm-twisting.

Even in a world neatly divided between domestic and external debt, this assumption did not hold for long. Printing money was increasingly seen as a costly way out of domestic debt commitments, threatening economic recovery. Meanwhile, as Ecuador showed in 1998, governments were reluctant to impose their full legal and political might on domestic creditors, for a combination of political, economic, and financial reasons. First, local debt holders are often political elites whose support is essential to a government in financial crisis. Second, with the growth of domestic banks that hold people's deposits and lend to companies and governments, restructuring domestic debt on punitive terms could have wide-ranging consequences.

Government debt often dominates a banking system's assets; writing it down could wipe out savings, foreclose credit to the private sector, and disrupt the payments system just when all these are needed for economic recovery. Restructuring debt held by

* International Affairs Fellow, Council on Foreign Relations.

${ }^{1}$ See <http://www.bis.org/statistics/secstats.htm>, at 85, 92. 
pension funds could wipeout people's savings. Whether or not governments guaranteed deposits, they would be expected to recapitalize the banks, so that writing down the debt claim on the government merely gives rise to another claim on the same resources.

More generally, squeezing residents does not help a country's balance of payments or stem the outflow of resources from an economy in crisis-it essentially redistributes the losses within, like a tax. This tax on domestic debt holders is best viewed in the context of broader economic contraction and policy adjustment: the same residents bear the brunt of devaluation, economic contraction, policy adjustment (including higher taxes and interest rates), and debt default. In economic if not legal terms, funds recovered from nonresidents are an inflow. Moreover, foreign investors tend to be more diversified-exposed to some but not all of these risks, and to a lesser degree.

All this economic reasoning is rarely persuasive to a foreign creditor who is effectively asked to subsidize the privileged treatment of domestic creditors who are not legally senior to the foreigner. Nondiscrimination is increasingly the rallying cry of foreign investors in financial crises. Even the sob story about wiping out people's savings can be read as asking foreigners to bankroll bailouts of domestic bank creditors and equity holders, who are not infrequently corrupt and politically well-connected.

In a world where domestic and external debt are clearly segregated-foreign and domestic residents hold different instruments-foreigners can condition their restructuring on what they see as equitable treatment of the domestic holders. This is the approach often discussed in connection with the IMF's sovereign bankruptcy proposal ${ }^{2}$ and collective action clauses (CACs). ${ }^{3}$ It mirrors the logic of domestic bankruptcy, where different economic interests are presumed to be represented by different legal instruments. Bankruptcy regimes tend to disregard the identity of the creditor, striving for identical treatment of all those holding the same instruments.

Yet the bankruptcy analogy breaks down in today's sovereign debt world, where one instrument can represent investors whose economic and political interests diverge wildly in crisis. Recent liberalization of capital movements has produced a world where the nationality of the holder and the currency and legal aspects of the instrument have decoupled and recombined in every way possible. For example, in Russia in 1998, both foreigners and domestic banks were holding GKOs, bonds denominated in rubles and governed by Russian law. In Mexico in 1995, both local banks and foreign investors bought high-yielding Tesobonos, domestic-law bonds indexed to the dollar, with dollars borrowed cheaply abroad. In Argentina in 2001, local banks and pension funds were heavily invested in the country's foreign-currency, foreign-law bonds. Similarly, domestic residents are heavy investors in the external debt of Lebanon, Uruguay, and Turkey.

We are just beginning to deal with the policy and transactional implications of this phenomenon. Mechanically, there are three ways of approaching it:

- Offer different restructuring terms to different holders of the same instruments (Russia's restructuring of the GKOs post-1998);

- Try to move domestic holders into different instruments (Argentina in December 2001 converted $\$ 41$ billion of foreign bonds into local loans); or

\footnotetext{
${ }^{2}$ See, e.g., International Monetary Fund, Sovereign Debt Restructuring Mechanism—Further Considerations, Aug. 14, 2002, available at <http://www.imf.org/external/np/pdr/sdrm/2002/081402.pdf>.

${ }^{3}$ See, e.g., Lee C. Bucheit, The Search for Intercreditor Parity, 8 L. \& Bus. Rev. AM. 78 (1998).
} 
- Offer the same terms to holders of the same instruments, then compensate residents on the side, e.g., though bank recapitalization.

The choice will depend on the economics and politics of a given crisis, but at this stage in the evolution of emerging-market sovereign debt, this much is becoming clear: First, a bipolar framing where foreign creditors are negotiating against the people's government no longer describes today's complex sovereign restructurings. Domestic creditors can be pitted openly against both their government and foreign creditors, but may align with either. Second, looking at any one of the characteristics that describe external and domestic debt (be it currency, residence, or governing law) to the exclusion of others will likely miss a significant part of the restructuring challenge. Finally, the principle of nondiscrimination between foreign and domestic holders is difficult if not impossible to uphold in crisis.

The implications of these lessons could be significant. Among them, it is worth thinking about the implications of domestic and foreign creditors being paid the same yield for taking different risks. On the other hand, market reports suggest that external creditors sometimes acquiesce in differential treatment inasmuch as it contributes to recovery and the value of the debt they hold.

Complex as it is, the evolution of sovereign debt is only part of the increasing complexity of emerging-market finance. The growing phenomenon of private and subsovereign actors borrowing directly abroad (prevalent in Asia in the runup to the 1998 crisis, and significant in Argentina and Brazil today) and its implications for government finances, cross-border capital flows, wealth distribution and economic reform after a crisis are beyond the scope of this panel, yet immensely important for understanding the broader story of globalization and development today.

\section{REMARKS BY ROBERT B. GRAY*}

The International Primary Market Association (IPMA), which I represent, is the Londonbased association of underwriters that is responsible for new-issue market practices for international bonds. Our members include all major investment and commercial banks active in international capital markets. Our effectiveness relies on our ability to balance the reasonable, or even unreasonable, expectations of issuers and investors in the interest of maintaining an efficient capital market for both.

IPMA has been cooperating with six other trade associations on a common privatesector position on crisis resolution. The group has finalized model collective action clauses (CACs) for inclusion in bond contracts and a draft code of conduct for international issuers and investors. We do believe that, taken together, both initiatives could make sovereign debt workouts more orderly. We argue that they will do the job better than a statutory mechanism, such as the sovereign debt restructuring mechanism (SDRM).

The International Monetary Fund (IMF) has a strong conviction that an SDRM would benefit the workout process by allowing debtors to initiate restructurings earlier than may otherwise be possible. I congratulate the IMF for the rigor of its analysis of the benefits of a statutory regime, but, unfortunately, the SDRM would compromise rights that creditors are anxious to protect. The case for a statutory bankruptcy mechanism hangs on a very thin thread: the benefit of being able to aggregate voting claims across a range of loan and debt instruments. Unfortunately, at the end of that thread hangs a sword

* Chairman, International Primary Market Association. 
of Damocles that could pose a serious threat to capital flows to the world's emerging economies. This is the view not just of investors and underwriters but, more important, of the issuers themselves.

I am here concerned with three aspects of the market-based versus statutory-based approaches to crisis resolution:

(1) The practicalities of involving bondholders in sovereign debt restructurings: How effective has the market been in achieving creditor coordination? It is clearly more difficult to get bondholders to act together than a group of lending banks.

(2) Why a voluntary market-based approach to crisis resolution is preferable to a statutory approach: Here I touch on the work of our group of associations in drafting model CACs. Such clauses are now accepted by all the key players as an important part of the evolving financial architecture. I argue that little divides the private sector from the official sector, not least the working group established by the G- $10^{1}$ to examine the issue, when it comes to the precise form of these clauses.

(3) What can be done to improve existing creditor coordination processes without doing violence to creditors' rights. How do bondholders face involvement in IMF or Paris Club-led restructurings? The idea that in recent times the official sector has bailed out private creditors is a myth. Bondholders, and banks for that matter, are aware that they should absorb losses commensurate with the risks that they take. Long before a default or rescheduling actually occurs, emerging market bonds will typically experience dramatic falls in price, with the holders suffering an immediate mark-to-market loss. Ecuador's eurobonds were trading at half their face value even before it missed its first payment on its Brady bonds. One of the judgments bond investors have to make is whether a sovereign that may be able to repay has the political will to make the sacrifices required to honor its obligations. Sovereign borrowers are not subject to the ultimate remedy of insolvency proceedings and liquidation. Bondholders understand that the threat of litigation is effectively the only card that they have to play, and even this card is hard for an individual bondholder to play because it is usually uneconomic for a bondholder to try to enforce rights directly.

Since bondholders have such limited remedies, it is not surprising that they expect workouts to be voluntary and inclusive. It is also not surprising that they react negatively to initiatives that impair, or even appear to impair, their rights. However, bondholders are increasingly aware that their interests are best served by collective action, even if that means accepting limits on their ability to act individually. After all, CACs were first introduced to protect creditors from each other, not to strengthen their hand with the debtor. Unbridled freedom of individual action for one creditor can negatively affect other creditors holding the same type of instrument. The key issue is how we can institutionalize the principle of collective action to make creditor coordination more effective. Through qualified majority voting, bondholders should be able to modify the terms of a bond contract in a way that is binding on all of them. Qualified majority voting reduces both the incentives for any bondholder to seek an individual settlement and the ability of a rogue creditor to hold for ransom the prospect of a reasonable debt settlement.

\footnotetext{
${ }^{1}$ The G-10 (Group of Ten) refers to a group of eleven developed countries that have agreed to participate in the General's Arrangements to Borrow. The BIS, European Commission, IMF, and OECD are also official observers of the activities of the G-10.
} 
This idea is something to which U.S. bondholders have come late, unless one harks back to the 1930s. The Mexico bond is the first Securities and Exchange Commission registered issue to include a qualified majority voting clause in recent times, although earlier 144A bonds ${ }^{2}$ from Egypt and Lebanon pointed in this direction. Significant differences between bonds have been documented under different governing laws. Under New York and German law, bond contracts typically have required unanimous agreement among bondholders before an agreement with the debtor can be reached. Although in the case of German law, this may be a matter of statute (perhaps the Rights of Bondholders Law of 1899), the indications are that CACs are not incompatible with German law. In the case of sovereign bonds under English law, since the nineteenth century 75 percent, two-thirds, and even as few as 25 percent of the bondholders can agree to a restructuring - something that bondholders, for reasons that we can discuss, have taken in their stride. These English clauses operate very much within the framework of a bondholders' meeting: if there is no quorum at the first meeting, a lower quorum typically is required at a second meeting, which is how such low percentages can arise.

The challenge in our market, and perhaps to a lesser degree here in the United States, is how to bring bondholders to the negotiating table. It is particularly difficult to identify and mobilize holders of bearer bonds, which are still a feature of our market. Where bondholders need to be lobbied, it has to be done through the international clearing systems, Euroclear and Clearstream, and through advertisements in the financial press. The international clearing systems will not disclose to an issuer or its advisers the identity of those who have positions in the bonds. (I understand that the Depository Trust Company makes the position on this different in the United States.) Notices or requests for proxies are given to our clearing systems which pass them on to their participants. These participants are typically custodians, who in turn are expected to pass all communications on to the beneficial owners, but the issuer or its advisers have no way to know whether that has actually happened. Should the beneficial owner wish to vote its bonds, the chain operates in reverse. If an issuer is in default, the clearing systems will seek to have defaulted bonds withdrawn from their system to be held by the beneficial owner directly.

Unwieldy as this all sounds, the system can be made to work. The exchange offers for Ukraine and Ecuador certainly attracted high levels of bondholder support, well over 95 percent. The high response level was due to a combination of factors-the energetic efforts of the banks executing the exchange offers and the effectiveness of the "exit consent" mechanism-but equally important was the flexibility that allowed the bondholders to vote their bonds through written proxies and even through the Internet. These cases are important because they prove that creditor coordination can be effective.

Which brings us neatly to my second topic: why a voluntary, market-based approach is preferable to a statutory approach like the SDRM. I do not doubt that the IMF's proposal for an SDRM has evolved to the point where it is highly creditor-friendly. What divides us from the Fund is the feasibility of achieving collective action across a broad range of loan and bond instruments.

The Fund has found what it believes to be an Achilles heel in the current workout regime: the difficulty of achieving effective creditor coordination when an issuer has outstanding a plethora of bond issues documented under different governing laws. The Fund view is that rogue creditors are able to obstruct a restructuring by taking control of one or more bond issues and holding out for better terms. As a result, the Fund

\footnotetext{
${ }^{2}$ Rule 144A bonds are securities which, in accordance with General Rules and Regulations promulgated under the Securities Act of 1933, may only be reoffered to qualified institutional buyers, as a result of which they enjoy exemption from the broader information requirements applicable to securities offered to the public.
} 
argues, there is a the case for aggregation of multiple bond issues for voting purposes, so as to dilute the role of any rogue creditor. Aggregation could certainly be effective in eroding the power of the rogue creditor, but I question the desirability of an SDRM that imposes a statutory aggregation scheme on outstanding bond claims, asking:

- At a philosophical level, do the benefits of aggregation outweigh the demerit of direct interference in contractual rights?

- At a more practical level, is the need for aggregation proven?

Apparently I am more optimistic than the IMF that CACs can be made to work across a broad range of individual bond issues and syndicated loans without the need for statutory remedies. The key is transparency: If bank lenders or holders of an individual bond issue feel that they are being treated fairly in relation to other creditors, they are more likely to cooperate. If the necessary majority cannot be achieved, for whatever reason, exit consents offer an alternative market-based remedy. With the exit consent mechanism, bondholders are strongly motivated to accept an exchange offer to avoid being left holding bonds that have been tainted by amendments to nonpayment terms, such as negative pledge or sovereign immunity, instigated by the holders. Although viewed by many investors as a backdoor usurpation of their rights, exit consents have proved an important addition to the collective action armory, and an important demonstration of the creativity of the private sector when left to its own devices.

Although cases like Elliott v. Peru ${ }^{3}$ appear to have convinced the Fund that rogue creditors weigh heavily on the sovereign debt restructuring process, in reality, there is no recent case where rogue creditors have blocked a restructuring. The risk of rogue creditor disruption is greatest after a restructuring has been carried out; at this stage, rogue creditors can take control of residual securities that may not have been part of the restructuring. If the objective of the SDRM is to weaken the role of rogue creditors, it is a disproportionate response to an imperfectly perceived problem.

Precisely which types of CACs are likely to be accepted by the private sector? The key CACs, already incorporated into English-law bond contracts by a broad range of emerging market issuers are:

- Majority action clauses, allowing a qualified majority of creditors to agree to a change in the terms of a debt contract that binds all the bondholders;

- Nonacceleration clauses, requiring the concurrence of a minimum threshold of bondholders before immediate repayment of principal after default can be demanded; and

- Collective representation or engagement clauses, defining mechanisms for coordinating discussions and possible action between the issuer and bondholders (ideally through a trustee).

The Mexico bond is a good example of how these clauses can be structured to balance the interests of both issuer and bondholders. The majority action level at 75 percent was lower than some investors might like, but Mexico gave something back to investors by broadening the range of reserve matters where any amendments would require approval, thereby making the use of exit consents more difficult.

\footnotetext{
${ }^{3}$ In June 2000 Elliott Associates obtained a judgment against Peru for $\$ 56$ million with respect to defaulted commercial loans that had been guaranteed by Peru. Subsequently Elliott Associates successfully obtained an order in the Brussels court restraining Euroclear from accepting or paying out cash from Peru to pay interest due on certain Brady bonds. Peru decided to settle with Elliott Associates in order to avoid default on the Brady bond payments.
} 
In the debate on CACs, most attention has been paid to the majority action clause. It is now accepted that a supermajority rather than unanimity should be required for amending core provisions, such as modifying scheduled principal or interest payment dates or amounts, reserved matters the definition of which was greatly broadened in the Mexico case.

How should the supermajority be defined? It should reflect the market experience to date with hold-out creditors, those who may withhold their vote in the hope of getting a better deal, but it should also recognize that an apparent hold-out creditor may merely be a passive creditor, which may value its anonymity. Nor can we ignore the potential for sovereigns to influence the process by acquiring or controlling creditor positions. However the majority is defined, the denominator should exclude debt held or controlled by the sovereign debtor.

We should also rely less on bondholder meetings when more modern techniques for collecting proxy votes may work better. Recent restructurings have taken the form of exchange offers where bondholders are invited to exchange their bonds for new bonds with longer maturities and lower coupons, giving the debtor some debt relief. The use of exchange offers is a pragmatic response to the difficulty of getting bondholders to a meeting to vote to amend their bonds. But exchange offers have their disadvantages. Inevitably with an exchange, some of the original bondholders, either because they are hostile to the idea or merely passive, will not tender their bonds. The part of the original bond issue that remains outstanding can fall into the hands of rogue creditors, who may then become a thorn in the side of the debtor. Far better that the original bond should be amended so as to bind all creditors.

The nonacceleration clause, which governs acceleration and deceleration of debt obligations, has received less attention. In my view, it is this clause that can do the most to shackle rogue creditors and reduce any risk of precipitous litigation. A nonacceleration clause limits the ability of a single rogue creditor to accelerate the bond without support from other creditors; it is particularly effective when combined with a strong provision for collective representation, such as the use of trustees.

There are ways the creditor coordination process can be improved so as to make debt restructuring more orderly. I draw most of my conclusions from the CAC work of our group of seven trade associations, but in some respects I go further than some of my collaborators in the private sector. I am an unashamed believer that the Englishlaw approach is better for both issuers and investors.

It has taken the current debate on sovereign debt restructuring to focus serious market attention on the fine points of sovereign bond documentation in general and CACs in particular. Perhaps it should not be a surprise that the market is not noticeably aware of what appear to be only subtle differences between contracts under different governing law. The greater apparent protection for bondholders under New York or German law has not translated into superior price performance for New York or German law over English-law bonds. The market's view, borne out in practice, is that no restructuring will favor one group of bondholders over another on the basis of whether or not their contract includes CACs or whether it is governed by one law versus another. Borrowers simply follow the practice of the time in the market in which their bonds they are issued; as a result, the same borrower will include a unanimity provision in its New York-law contracts but a qualified majority voting provision in its English-law contracts. The precise form of such clauses does not figure in pre-mandate negotiations between issuer and underwriter, or even in the period between when a bond issue is mandated and when it is launched. It has been assumed that such matters will be left to each party's legal counsel. 
The decision by the United Mexican States to include a qualified majority provision in a New York-law bond contract will likely change all that. Issuers will have to be proactive in deciding whether or not to include any CACs in their bond documentation. Debt issuance programs give them a particular opportunity to standardize their bond documentation. The market would welcome standardization; it is important that these clauses be as uniform as possible.

In the period during which bond issues are launched and sold, there is little time for investors to gauge the pros and cons of different provisions. Their main concern is whether a given bond represents good value relative to other investment opportunities. The least desirable outcome would be for a particular issuer's CACs to become a source of competition: for example, if an underwriter marketed itself to an issuer as being able to launch an issue with a lower qualified majority level than its competitors, or if an issuer argued that a lower percentage of bondholders should be allowed to amend its bond terms because it had stronger credit than other issuers. What we need is for emerging-market and OECD issuers from a broad credit spectrum to follow Mexico's example. European Union issuers have stated their willingness to include CACs in their foreign currency bonds, as has Canada, but I am not convinced that issuers should be given financial incentives by the official sector, including the IMF itself, to introduce them. If issuers need incentives to adopt these clauses, that sends a strong signal that they may be undertaking something that is not in their interest. From their side, investors would view a system of incentives as official interference in the workings of the market. Far better that CACs should be adopted because they represent a win-win situation for issuers and investors-for issuers because they will be less vulnerable to the risk of rogue investors, and for investors because workouts should be more predictable and less protracted.

Underwriters may have to temper their competitive enthusiasm and encourage issuers to maintain standards of documentation and disclosure. The competitive enthusiasm of underwriters may be one reason why the use of trustees has virtually disappeared from market practice. To save the issuer a small amount of expense, underwriters failed to stress the value of appointing trustees. IPMA believes that trustees have an important role in improving creditor coordination. First, a bondholder trustee offers the best opportunity for effective creditor coordination. For a start, no bondholder can take unilateral action without involving the trustee. Litigation must be carried out by the trustee, and any recoveries through litigation are shared pro rata among all the bondholders.

Without a trustee, too, sharing becomes impractical. Without a trustee at the center of the process, it would be difficult to either induce a creditor that had made a disproportionate recovery to disgorge the excess or to determine which bondholders would be entitled to share. Would it be those holding the bonds when the issuer agreed to pay, those holding when the issuer actually paid, or those holding if a collecting bondholder actually disgorged his excess share? To use Lee Buchheit's analogy between bondholders and a group of theatregoers, would it be those that stayed to the end of the play, those who left at the interval or those who paid for their tickets but did not attend?

The second benefit of a trustee is that it provides a useful channel for communication between issuer and bondholders, given that, legally at least, neither the lead manager nor a fiscal and paying agent has any responsibility to communicate. Many U.S. investors seem to have some antipathy to the use of trustees, apparently grounded in the belief that U.S. trustees have been very passive. Trustees do stick closely to the text of the indenture in deciding what they are authorized to do. To quote Buchheit, they 
are "notoriously timid when confronted with situations in which their actions or their acquiescence could be seen as impairing the bondholders' rights."4 This strikes me as valid criticism not of the trustee concept but of how trustees have been allowed to behave in practice. Trustee timidity need not be a fact of life. In the international market, we have seen trustees take unilateral action to put debtor into default without consulting with bondholders because it believed that the circumstances justified such action.

Both issuers and investors can benefit from bringing sovereign debt crises to a quick resolution. Bondholders typically are not a homogeneous group; as a crisis develops, they tend to become even less homogeneous. The introduction of CACs into loan and bond contracts is an essential step forward. Protracted restructurings are not in the interest of either investors or issuers. From the creditors' viewpoint, the evidence is that the longer a bond is in default, the lower the recovery rate. From the borrowers' viewpoint, unresolved debt claims can help deny them further access to capital markets. CACs can help expedite the restructuring process.

We may take some comfort from knowing that things were even more difficult in the past. Some nineteenth century reschedulings dragged on for sixty years. In the $1920 \mathrm{~s}$ and 1930s Thomas Lamont of J.P.Morgan negotiated with the Mexican government on behalf of the International Committee of Bankers, which acted at that time for no less than 200,000 foreign bondholders. In the 1930 rescheduling, all accrued but unpaid interest was fully forgiven and the principal was rescheduled into a forty-five-year sinking-fund bond. Lamont had some battles with the official sector over the importance of protecting bondholder interests; ironically, perhaps, his antagonist was the U.S. government in the form of Secretary of State Dwight Morrow. Perhaps those goingson were debated at an earlier Annual Meeting of the American Society of International Law. I would like to think so.

\footnotetext{
${ }^{4}$ Lee Buchheit, The Collective Representation Clause, InT'L FIN. L. Rev. 10 (Sept. 1998).
} 